\title{
AUTISM SPECTRUM DISORDERS: NEUROTROPHINS ENTER THE DANCE
}

\author{
Rouzha Pancheva and Miglena Georgieva \\ Department of Hygiene, Faculty of Public Health, Medical University, Varna, Bulgaria and Department \\ of Pediatrics and Medical Genetics, Faculty of Medicine, Medical University, Varna, Bulgaria
}

\section{INTRODUCTION}

Autism spectrum disorders (ASD) is a group of lifelong neurodevelopmental disorders characterized by impairment in social interaction and communication, delayed and disordered language, restricted and stereotypic patterns of behaviour, interests and activities, and onset before 3 years of age. They are classified according to ICD 10 (1) (Table 1).

Autism spectrum disorders continue to increase at an

Table 1. F84 Pervasive developmental disorders

\section{F84.0 Childhood autism}

F84.1 Atypical autism

F84.2 Rett's syndrome

F84.3 Other childhood disintegrative disorder

F84.4 Overactive disorder associated with mental retardation and stereotyped movements

F84.5 Asperger's syndrome

F84.8 Other pervasive developmental disorders

F84.9 Pervasive developmental disorder, unspecified alarming rate with the most recent statistics released by the Centers for Disease Control (CDC) indicating an incidence of $1.14 \%$, or one in every 88 neurotypical children (2). Its ethiopathogenesis is poorly understood. Although a genetic origin has been recognized, it has been hypothesized a role for environmental factors, immune dysfunctions, and alterations of neurotransmitter systems. Sex-bias of ASD has a male to female ratio of approximately 4:1 (3). Recent findings from a study of more than 6 million ASD patients indicate that the prevalence of ASD seems to be increasing linearly from year to year (4).

The neurobiological basis for autism remains elusive. A variety of findings suggest disturbances of brain development as a key feature of pathophysiology (5). Recent studies show that the abnormal levels of neurotrophins, such as nerve growth factor (NGF), brain-derived neurotrophic factor (BDNF) and their relatives, might represent one of the aspects implicated in the pathogenesis of ASD (5-7). Studies on infants suggest that babies later diagnosed with ASD have smaller brain size at birth but undergo a rapid increase in brain volume during the first years of their life $(8,9)$. It has been hypothesized that

Received 15 December 2014, revised 22 December 2014, accepted 23 December 2014.

Correspondence to Dr Rouzha Pancheva, Department of Hygiene, Faculty of Public Health, Medical University, Varna, Bulgaria. Tel.: +359 899659873, E-mail: rouzha_pancheva@yahoo.com 
the formation of neuronal connections and the elimination of inappropriate connections happens not in a physiological manner. Neuropathological studies on ASD show smaller neuronal sizes, decreased dendritic branches and alterations in dendritic spine density and shape in cortical projection neurons (10). Likewise, increased inhibitory synaptic transmission (11) and decreased Purkinjie cells in vermis and hemispheres of the cerebellum (12). There are some dysregulations also in the reelin, a glycoprotein secreted by neurons that is critically involved in the corticogenesis (13). Reelin also promotes maturation of dendrites and dendritic spines (14). Some aspects of the relationship between developmental dendritic pruning and elevated mTORC1 signaling (15), and macroautophagy in ASD have been recently demonstrated (4).

To make the dance even more complicated, considerable attention has been recently centred upon the functionality and plasticity of glial cells, particularly astrocytes (16). These cells participate in normal brain development and also in neuropathological processes. Data from an ASD animal model highlights that the astrocytic clearance and destination of glutamate in the synaptic cleft in tripartite synapses might be altered in autism, pointing out important aspects to be considered from both pathophysiologic and pharmacological approaches in ASD (17). The evidence also implicates dysfunctional signaling via $\mathrm{Ca}^{2+}$-dependent mechanisms, extracellular signal-regulated kinases (ERK)/ phosphatidylinositol-3-kinases (PI3K) and neuroliginneurexin-SHANK as convergent molecular mechanisms in ASD (14).

Whatsoever, the molecular mechanisms underlying these changes are yet not fully understood. As mentioned above, neurothrophic factors are one of the most prominent vectors influencing the development and maintenance of the central and peripheral nervous system. They are a family of proteins that induce the survival, development, and function of neurons. They exert a key role in brain development and maintenance of neurons and are able to critically influence the formation and elimination of neuronal connections. Given these properties they have been recently discussed as promising candidates playing a role in autism pathobiology and being responsible at least partially for the alterations in ASD (5-7).

The neurotrophin family of proteins consists of NGF, proNGF, BDNF, pro-BDNF, neurotrophin-3 (NT-3), NT-4/5, NT-6, NT-7 (18). Here we will dance round all these factors. Besides the neurotrophins, there are other protein families exerting neurotrophic actions, such as glial cell line-derived neurotrophic factor (GDNF), ciliary neurotrophic factor (CNTF) and insulin-like growth factors (IGF), which are out of the scope of present Dance round.

\section{NGF}

It has been hypothesized that abnormal levels of serum NGF may represent a serological marker for autistic children who may develop cognitive impairment, regression and finally epilepsy. The objective of a preliminary study was to measure serum NGF concentrations of autistic children and compare these levels with those of healthy children (19). Consecutive children who were referred to a pediatric unit were investigated and serum samples analyzed for NGF levels. Forty-nine autistic children and an equal number of healthy children (control group) were included in the study. Serum NGF concentrations were significantly higher in the study group compared with the control group. This preliminary findings suggested that enhanced serum NGF concentration could be used as a potential diagnostic tool in ASD.

In another study with rats, where a model of maternal infection was simulated, NGF expression was significantly increased in neonatal cortex, which was speculated to represent a potential mechanism through which maternal infection increased the risk for neurodevelopmental disorders (20). In a third study the level of NGF plasma levels were lower in patient with Rett syndrome with prolonged corrected QT interval in comparison with those with the same syndrome but normal QT (21). On the other hand, a previous study (22) detected normal levels of NGF in the cerebrospinal fluid in autism and low to negligible levels in Rett syndrome, which was in agreement with the different morphological and neurochemical findings (brain growth, affected brain areas, neurotransmitter metabolism) in the two syndromes. A suggestion was made to use cerebrospinal fluid NGF as a biomarker for differentiation of patients with autism from those with Rett syndrome.

In another study the level of autoantibodies to nerve growth factor was evaluated in blood serum of 163 children with different forms of mental dysontogenesis of different origin (23). Significant elevation of the level of autoantibodies was found in all forms of psychic dysontogenesis. The most significant elevation of the level of autoantibodies, as compared with the controls (45 children), was characteristic for endogenic forms of dysontogenesis (schizophrenia, early children's autism, schizotypic diathesis). The level of autoantibodies was also found as an indicator of the acuteness 
of the pathologic state. Besides, its elevation was observed 1-2 weeks prior to the onset of the clinical exacerbation.

\section{BDNF}

In a commonly used animal model of autism a transient increase of both mRNA ${ }^{\mathrm{BDNF}}$ and BDNF protein levels was detected in the embryonic mouse brain (24). This model was created by the administration of valproic acid to pregnant animals at gestational days 12.5 (E12.5) or E13.5 which leads to autistic-like symptoms in the offspring. Of the nine 5'-untranslated exons of the mouse BDNF gene, only expression of exons I, IV and VI was stimulated by valproic acid in utero. The conclusion of the study was that in light of the well-established role of BDNF in regulating neurogenesis and the laminar fate of postmitotic neurons in the developing cortex, an aberrant increase in BDNF expression in the fetal brain may contribute to valproic acid-induced cognitive disorders by altering brain development.

BDNF elevation in newborn blood serum was found to predict intellectual/social developmental abnormalities. Thus, the circulating BDNF levels and IgG/IgM autoantibodies to BDNF were measured in children with autism, healthy children, and children with non-neurological illness (25). Mean BDNF levels were elevated in children with autism compared to healthy or children with non-neurological illnesses. Mean IgG and IgM BDNF autoantibodies were significantly elevated in children with autism compared to healthy children but not to children with non-neurological illness. The conclusion of the study was that children with autism have higher autoantibodies to BDNF compared to controls. The presence of both BDNF autoantibodies and elevated BDNF levels in some children with autism suggests a previously unrecognized interaction between the immune system and BDNF.

Although this observation is in harmony with results from other studies showing high concentrations of BDNF in autistic children (26), in another study the opposite result is reported (27). The level of serum BDNF was investigated as well as its age-related changes in healthy controls in comparison to autistic subjects. The concentration of BDNF was measured after its gradual released from platelets at 4 C. In healthy controls, the serum BDNF concentration increased over the first several years, then slightly decreased after reaching the adult level. There were no sex differences between males and females. In the autism cases, mean levels were significantly lower in children 0-9 years old compared to teenagers or adults, or to age-matched healthy controls, indicating a delayed
BDNF increase with development.

In another study (28), subjects were recruited from a hospital in the Netherlands - 37 ASD patients [age around 10 years; body mass index $\left.(\mathrm{BMI})=18.0 \pm 3.7 \mathrm{~kg} / \mathrm{m}^{2}\right]$ and 37 controls (age around 10 years; BMI $=17.6 \pm 3.0 \mathrm{~kg} / \mathrm{m}^{2}$ ). It has been noted that there were not any age-related changes in the serum levels of BDNF as in other studies (27).

In a population of Chinese children aged around 4 years the potential role of BDNF was explored (29). Level of BDNF was assayed with enzyme-linked immunosorbent assay methods, and severity of ASD was evaluated with the Childhood Autism Rating Scale (CARS) Score. The results indicated that the median serum BDNF levels were significantly higher in children with ASD as compared to normal cases. The investigators found that an increased risk of ASD was associated with BDNF levels more than $15.0 \mathrm{ng} / \mathrm{ml}$. This study demonstrated that serum BDNF levels were associated with ASD in a Chinese population, and higher levels could be considered as an independent contributing factor for ASD.

Differences in the analytic platforms used in the above cited studies, assay and sample test methods, and subject populations may explain the inconsistencies among studies $(30,31)$. Furthermore, circadian and/or seasonal and sex dependent changes in the level of BDNF is recognized in some studies (27, 32-34).

\section{NEUROTROPHINS-3, -4/5}

A paucity of cerebellar Purkinje cells and abnormalities in the inferior olive are among the best-documented changes in brain structure in autism (12). NT-3 plays an important role in glutamatergic synapse development in vitro (35) and this could be a mechanism influencing brain development in autism. Valproic aicd exposure in utero (in a rat model of autism) induced small increases in the expression of mRNA ${ }^{\mathrm{NT}-3}$ (2.5-fold) and mRNA ${ }^{\mathrm{NT}-4 / 5}$ (2-fold) (24). Expression of the neurotrophin receptors, TrkA, TrkB and TrkC were minimally affected, while levels of the low-affinity panneurotrophin receptor, $\mathrm{p} 75^{\mathrm{NTR}}$, doubled. In contrast to this investigation, in a study of Nelson et al (31), using a double-antibody immunoaffinity assay (Luminex) and ELISA technology, the concentrations of certain neurotrophins was measured in pooled samples eluted from archived neonatal blood of children with later diagnosed autism, Down syndrome, very preterm birth, or term control infants. Concentrations in control subjects differed by age: BDNF rose markedly with age, while NT-3 and NT- $4 / 5$ concentrations were lower in adults than in 
Table 2. A summary of the studies on neurotrophobiology of autism spectrum disorders

\begin{tabular}{|c|c|c|c|c|}
\hline Neurotrophin & Target population & Sample used & Main findings & Reference \\
\hline NGF & Autistic and healthy children & Blood serum & $\begin{array}{l}\uparrow \text { serum level of NGF in autistic compared to } \\
\text { healthy children }\end{array}$ & 19 \\
\hline NGF & Neurodevelopmental disorders & $\begin{array}{l}\text { Neonatal } \\
\text { cortex }\end{array}$ & Increased expression & 20 \\
\hline NGF & $\begin{array}{l}\text { Rett syndrome with prolonged } \\
\text { corrected QT interval }\end{array}$ & Plasma & $\begin{array}{l}\downarrow \text { Serum level of NGF compared with Rett } \\
\text { syndrome with normal corrected QT interval }\end{array}$ & 21 \\
\hline NGF & Autism and Rett syndrom & CSF & $\begin{array}{l}\text { Normal CSF NGF level in autism } \downarrow \text { in Rett } \\
\text { syndrom }\end{array}$ & 22 \\
\hline $\begin{array}{l}\text { Autoantibodies } \\
\text { to NGF }\end{array}$ & $\begin{array}{l}\text { mental dysontogenesis of endogenic, } \\
\text { residual-organic, psychogenic and } \\
\text { deprivative origin }\end{array}$ & Blood serum & $\begin{array}{l}\uparrow \text { level of autoantibodies compared to } \\
\text { controls }\end{array}$ & 23 \\
\hline $\begin{array}{l}\text { NGF, BDNF, NT- } \\
3, \text { NT-4/5 }\end{array}$ & $\begin{array}{l}\text { autistic spectrum disorders, mental } \\
\text { retardation without autism and } \\
\text { cerebral palsy, and control children }\end{array}$ & $\begin{array}{l}\text { Neonatal } \\
\text { blood }\end{array}$ & No significant changes & 7 \\
\hline BDNF & Offsprings in an animal model of autism & Brain & $\uparrow$ BDNF 5-6-fold & 24 \\
\hline BDNF & $\begin{array}{l}\text { Children with autism, childhood } \\
\text { disintegrative disorder, healthy children, } \\
\text { non- neurological illnesses }\end{array}$ & Blood serum & $\begin{array}{l}\uparrow \text { in autism and disintegrative disorders } \\
\text { compared to healthy children and non- } \\
\text { neurological illnesses }\end{array}$ & 25 \\
\hline $\begin{array}{l}\lg \mathrm{G}, \lg \mathrm{M} \text { BDNF } \\
\text { autoantibodies }\end{array}$ & $\begin{array}{l}\text { Children with autism, childhood } \\
\text { disintegrative disorder, epilepsy, healthy } \\
\text { children, non- neurological illnesses, } \\
\text { epilepsy }\end{array}$ & Blood serum & $\begin{array}{l}\uparrow \text { in autism, disintegrative disorders and } \\
\text { epilepsy compared to healthy children and } \\
\text { non- neurological illnesses }\end{array}$ & 25 \\
\hline BDNF & $\begin{array}{l}\text { Pregnant women, children with } \\
\text { autism, mental retardation and typical } \\
\text { development }\end{array}$ & blood & $\begin{array}{l}\text { No change in mid-pregnancy and neonatal } \\
\text { specimens }\end{array}$ & 30 \\
\hline BDNF & Autistic and healthy children & $\begin{array}{l}\text { In serum, } \\
\text { gradually } \\
\text { released from } \\
\text { platelets }\end{array}$ & $\begin{array}{l}\text { Circadian but not seasonal changes. } \\
\downarrow \text { in autistic children 0-9 years old compared } \\
\text { to teenagers or adults, or to age-matched } \\
\text { healthy controls }\end{array}$ & 27 \\
\hline BDNF, NT-4 & $\begin{array}{l}\text { autism and mental retardation, or } \\
\text { healthy controls }\end{array}$ & Blood serum & $\begin{array}{l}\uparrow \text { BDNF in autistic group (and the mental } \\
\text { retardation compared to the control group. } \\
\uparrow \text { serum NT-4 concentration in the mental } \\
\text { retardation group }\end{array}$ & 6 \\
\hline BDNF & ASD and controls & Blood serum & No age dependent changes & 28 \\
\hline BDNF & ASD and controls & Blood serum & $\uparrow$ in autistic children & 29 \\
\hline NT-3, NT-4/5 & $\begin{array}{l}\text { autism, Down syndrome, very preterm } \\
\text { birth, or term control infants }\end{array}$ & $\begin{array}{l}\text { Neonatal } \\
\text { blood pooled } \\
\text { samples }\end{array}$ & $\begin{array}{l}\downarrow N T-3, N T-4 / 5 \text { in autistic children compared } \\
\text { to controls }\end{array}$ & 31 \\
\hline IGF-1,-2 & Autism and controls & CSF & $\begin{array}{l}\downarrow \text { IGF- } 1 \text { in autistic children compared to } \\
\text { controls, IGF- } 2 \text { no difference between groups }\end{array}$ & 37 \\
\hline IGF-1 & Autism and controls & CSF & $\begin{array}{l}\downarrow \text { IGF- } 1 \text { in autistic children compared to } \\
\text { controls }\end{array}$ & 36 \\
\hline $\begin{array}{l}\text { Glutamat } \\
\text { uptake }\end{array}$ & Male rats in an animal model of autism & Hippocampus & $\begin{array}{l}\text { unchanged at day } 15 \\
\uparrow 160 \% \text { at day } 120\end{array}$ & 17 \\
\hline $\begin{array}{l}\text { Glutamine } \\
\text { synthetase } \\
\text { activity }\end{array}$ & Male rats in an animal model of autism & Hippocampus & $\begin{array}{l}\uparrow 43 \% \text { at day } 15 \\
\downarrow 28 \% \text { at day } 120\end{array}$ & 17 \\
\hline $\begin{array}{l}\text { Glutathione } \\
\text { content }\end{array}$ & Male rats in an animal model of autism & Hippocampus & $\begin{array}{l}\text { unaltered at day } 15 \\
\uparrow 27 \% \text { at day } 120\end{array}$ & 17 \\
\hline
\end{tabular}


newborn infants. In samples from autistic subjects, NT-3 levels were significantly lower than controls and an increase in VIP approached statistical significance. Concentrations of NT-4/5 were correlated in infants with autism but not in controls. Some of these results differ from earlier findings using a singleantibody recycling immunoaffinity chromatography (RIC) system. The mean concentration of NT-3 tended to be lower in children with later-diagnosed autism than in control subjects. The difference was of borderline statistical significance. Values for NT-4/5 did not distinguish children with autism from control infants. Thus measurement by Luminex again did not confirm the previous observations by RIC (7). There were no changes again in the level of NT-4/5 also in another study, in which the BDNF level was markedly increased (6). Meanwhile, for the possible involvement of insulin-like growth factor-I (IGF-I) in the development of autism, see $(36,37)$.

\section{CODA}

The present Dance round demonstrates that blood serum and/ or cerebrospinal fluid levels of the neurotrophins NGF, BDNF, NT-3 and NT-4/5 may be associated with the pathogenesis of ASD (Table 2). Indeed, much more research is necessary in order to draw final conclusions about the possible link between the amount of neurotrophins and ASD in different population and age groups, and the methodology and biological samples which could be used for this purpose.

\section{CONFLICT OF INTEREST}

The authors declare no conflict of interest.

\section{REFERENCES}

1. The ICD-10 Classification of Mental and Behavioural Disorders. Clinical descriptions and diagnostic guidelines. WHO; http://www.who.int/classifications/icd/en/ bluebook.pdf

2. CDC; Morbidity and mortality weekly report. Surveillance Summaries 2012. Prevalence of Autism Spectrum Disorders - Autism and Developmental Disabilities Monitoring Network, 14 Sites, United States, 2008: 1-19. http:/ www.cdc.gov/mmwr/pdf/ss/ss6103.pdf

3. Baron-Cohen S, Lombardo MV, Auyeung B, Ashwin E, Chakrabarti B, Knickmeyer R. Why are autism spectrum conditions more prevalent in males? PLoS Biol 2011; 9: e1001081. DOI:10.1371/journal.pbio.1001081

4. Keyes KM, Susser E, Cheslack-Postava K, Fountain C, Liu K, Bearman PS. Cohort effects explain the increase in autism diagnosis among children born from 1992 to 2003 in California. Int $J$ Epidemiol 2012;41:495-503. DOI: $10.1093 /$ ije/dyr193

5. Nickl-Jockscha T. Neurotrophic factors in autism spectrum disorders. In: Comprehensive Guide to Autism. Springer New York 2014: 741-754.

6. Kaoru M, Narita N, Sakuta R, Miyahara T, Naruse H, Okado $\mathrm{N}$, et al. Serum neurotrophin concentrations in autism and mental retardation: a pilot study. Brain Dev 2004; 26: 292295. DOI:10.1016/S0387-7604 (03)00168-2

7. Nelson, KB, Grether JK, Croen LA, Dambrosia JM, Dickens BF, Jelliffe LL, et al. Neuropeptides and neurotrophins in neonatal blood of children with autism or mental retardation. Ann Neurol 2001; 49: 597-606. DOI:10.1002/ana.1024

8. Courchesne E, Kathleen Campbell K, Solso S. Brain growth across the life span in autism: age-specific changes in anatomical pathology. Brain Res 2011; 1380: 138-145. DOI:10.1016/j.brainres.2010.09.101

9. Dementieva YA, Vance DD, Donnelly SL, Elston LA, Wolpert CM, Ravan SA, et al. Accelerated head growth in early development of individuals with autism. Pediatr Neurol 2005; 32: 102-108. DOI:10.1016/j. pediatrneurol.2004.08.005

10. Hutsler JJ, Zhang H. Increased dendritic spine densities on cortical projection neurons in autism spectrum disorders. Brain Res 1309 2010: 83-94. DOI:10.1016/j. brainres.2009.09.120

11. Katsuhiko T, Blundell J, Etherton MR, Hammer RE, Liu $\mathrm{X}$, Powell CM, et al. A neuroligin-3 mutation implicated in autism increases inhibitory synaptic transmission in mice. Science 2007; 318: 71-76. DOI: 10.1126/science.1146221.

12. Kemper TL, Bauman M. Neuropathology of infantile autism. Mol Psychiatr 2002; 7: S12-3. DOI: 10.1097/00005072-199807000-00001

13. 13. Fatemi, S. Hossein. Reelin glycoprotein: structure, biology and roles in health and disease. Mol Psychiatr 2005; 10: 251-257. DOI:10.1038/sj.mp. 40016133

14. Stamou M, Streifel KM, Goines PE, Lein PJ. Neuronal connectivity as a convergent target of gene-environment interactions that confer risk for Autism Spectrum Disorders. Neurotoxicol Teratol 2013; 36: 3-16. DOI:10.1016/j. ntt.2012.12.001

15. Browing H, Klann E. Shaping dendritic spines in Autism Spectrum Disorder: mTORC1-dependent macroautophagy. Neuron 2014; 83: 994-996. DOI:10.1016/j. neuron.2014.08.021 
16. Yuskaitis CJ, Beurel E, Jope RS. Evidence of reactive astrocytes but not peripheral immune system activation in a mouse model of Fragile X syndrome. Biochim Bioph Acta - Mol Basis Dis 2010; 1802: 1006-1012. DOI:10.1016/j.bbadis.2010.06.015

17. Silvestrin RB, Bambini-Junior V, Galland F, Bobermim LD, Quincozes-Santos A, et al. Animal model of autism induced by prenatal exposure to valproate: altered glutamate metabolism in the hippocampus. Brain Res 2013; 1495: 52-60. DOI:10.1016/j.brainres.2012.11.048

18. Yanev S, Luigi A, Fiore M, Chaldakov GN. Neurotrophic and metabotrophic potential of nerve growth factor and brain-derived neurotrophic factor: Linking cardiometabolic and neuropsychiatric diseases. World J Pharmacol 2013; 2:982-992. DOI: 10.5497/wjp.v2.i4.92

19. Dinçel N, Ünalp A, Kutlu A, Öztürk A, Uran N, Ulusoy S. Serum nerve growth factor levels in autistic children in Turkish population: A preliminary study. Indian J Med Res 2013; 138: 900.

20. Gilmore JH, Jarskog LF, Vadlamudi S. Maternal infection regulates BDNF and NGF expression in fetal and neonatal brain and maternal-fetal unit of the rat. $J$ Neuroimmunol 2003; 138: 49-55. DOI:10.1016/S01655728(03)00095-X

21. Guideri FM. Acampa G, Calamandrei, Aloe L, Zappella MY, et al. Nerve growth factor plasma levels and ventricular repolarization in Rett syndrome. Pediatr Cardiol 2004; 25: 394-396. DOI:10.1007/s00246-0020406-y

22. Riikonen R, Vanhala R. Levels of cerebrospinal fluid nerve-growth factor differ in infantile autism and Rett syndrome. Dev Med Child Neurol 1999; 41: 148-152. DOI: $10.1111 / j .1469-8749.1999 . t b 00573$

23. Kozlovskaia G V, et al. Nerve growth factor autoantibodies in children with various forms of mental dysontogenesis and in schizophrenia high risk group. Zhurnal Nevrol Psikhiatr 1999; 100: 50-52.

24. Almeida LEF, Clinton DR, Krueger BK. Increased BDNF expression in fetal brain in the valproic acid model of autism. Mol Cell Neurosc 2014; 59: 57-62. DOI:10.1016/j. mcn.2014.01.007

25. Connolly AM, et al. Brain-derived neurotrophic factor and autoantibodies to neural antigens in sera of children with autistic spectrum disorders, Landau-Kleffner syndrome, and epilepsy. Biol Psychiatr 2006; 59: 354-363. DOI. org/10.1016/j.biopsych.2005.07.004
26. Theoharides TC, Athanassiou M, Panagiotidou S, Doyle R. Dysregulated brain immunity and neurotrophin signaling in Rett syndrome and Autism Spectrum Disorders. J Neuroimmunol 2015; 279: 33-38. DOI:10.1016/j. jneuroim.2014.12.003

27. Katoh-Semba, Ritsuko, et al. Age-related changes in BDNF protein levels in human serum: differences between autism cases and normal controls. Int J Dev Neurosci 2007; 25: 367-372. DOI:10.1016/j.ijdevneu.2007.07.002

28. Ramsey JM, Guest PC, Broek JA, Glennon JC, Rommelse $\mathrm{N}$, Franke B, et al. Identification of an age-dependent biomarker signature in children and adolescents with autism spectrum disorders. Mol Autism 2013; 4: 27. DOI:10.1186/2040-2392-4-27

29. Qing-biao Z, Liang-fu Jiang, Yuan-Jun Lu. Serum brainderived neurotrophic factor levels in Chinese children with autism spectrum disorders: A pilot study. Int J Dev Neurosci 2014; 37: 65-68. DOI:10.1016/j. ijdevneu.2014.06.013

30. Croen LA, Goines P, Braunschweig D, Yolken R, Yoshida CK, Grether JK, et al. Brain, derived neurotrophic factor and autism: maternal and infantperipheral blood levels in the Early Markers for Autism (EMA) study. Autism Res 2008; 1: 130-137. DOI: 10.1002/aur.14

31. Nelson PG, Kuddo T, Song EY, Dambrosia, J. M., Kohler $\mathrm{S}$, Satyanarayana G, et al. Selected neurotrophins, neuropeptides, and cytokines: developmental trajectory and concentrations in neonatal blood of children with autism or Down syndrome. Int J Dev Neurosci 2006; 24 : 73-80. DOI:10.1016/j.ijdevneu.2005.10.003

32. Miyazaki K, Mousro K. Mattson MP. BDNF mediates adaptive brain and body responses to energetic challenges. Trends Endocrinol Metab 2014; 25: 89-98. DOI:10.1016/j. tem.2013.10.006

33. Marc L, et al. Serum BDNF concentrations show strong seasonal variation and correlations with the amount of ambient sunlight. PloS One 2012; 7: e48046. DOI: 10.1371/journal.pone. 0048046

34. Nishichi R, Nufuji Y, Washio M, Kumagai S. Serum brain-derived neurotrophic factor levels are associated with dyssomnia in females, but not males, among Japanese workers. J Clin Sleep Med 2013; 9: 649. DOI: 10.5664/ jcsm. 2828

35. Blondel O, Collin C, McCarran B, Zhu X, Zamostiano R, Gozes I, et al. A glia-derived signal regulating neuronal differentiation. J. Neurosci. 2000; 20: 8012-8020. 
36. Vanhala R, Turpeinen U, Riikonen R. Low levels of insulin-like growth factor-I in cerebrospinal fluid in children with autism. Dev Med Child Neurol 2001; 43: 614-616.DOI: 10.1111/j.1469-8749.2001.tb00244.
37. Riikonen R, Makkonen I, Vanhala R, Turpeinen U, Kuikka J, Kokki H. Cerebrospinal fluid insulin-like growth factors IGF-1 and IGF-2 in infantile autism. Dev Med Child Neurol 2006; 48: 751-755. DOI: 10.1017/ S0012162206001605 